\title{
Article \\ The Roles of Orbital and Meltwater Climate Forcings on the Southern Ocean Dynamics during the Last Deglaciation
}

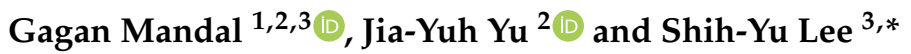 \\ 1 Earth System Science Program, Taiwan International Graduate Program, Academia Sinica, \\ Taipei 11529, Taiwan; gagan.iitroorkee@gmail.com \\ 2 Department of Atmospheric Sciences, National Central University, Taoyuan 32001, Taiwan; \\ jiayuh@atm.ncu.edu.tw \\ 3 Research Center for Environmental Changes, Academia Sinica, Taipei 11529, Taiwan \\ * Correspondence: shihyu@gate.sinica.edu.tw
}

check for

updates

Citation: Mandal, G.; Yu, J.-Y.; Lee, S.-Y. The Roles of Orbital and Meltwater Climate Forcings on the Southern Ocean Dynamics during the Last Deglaciation. Sustainability 2022, 14, 2927. https://doi.org/ $10.3390 /$ su14052927

Academic Editors: Baojie He, Jun Yang, Ayyoob Sharifi, Chi Feng and Marc A. Rosen

Received: 10 December 2021 Accepted: 25 February 2022 Published: 2 March 2022

Publisher's Note: MDPI stays neutral with regard to jurisdictional claims in published maps and institutional affiliations.

Copyright: (c) 2022 by the authors. Licensee MDPI, Basel, Switzerland. This article is an open access article distributed under the terms and conditions of the Creative Commons Attribution (CC BY) license (https:/ / creativecommons.org/licenses/by/ $4.0 /)$.

\begin{abstract}
The last deglacial climate evolution, from 19 to 9 thousand years before the present, represents the vital role of feedback in the Earth's climate system. The Southern Ocean played a fundamental role by exchanging nutrients and carbon-rich deep ocean water with the surface during the last deglaciation. This study employs a fully coupled Earth system model to investigate the evolution of Southern Ocean dynamics and the roles of changes in orbital and meltwater forcings during the last deglaciation. The simulation supports that the Southern Ocean upwelling was primarily driven by windstress. The results show that the melting and formation of Antarctic sea ice feedback influenced Southern Ocean surface buoyancy flux. The increase in Antarctic sea ice melt-induced freshwater flux resulted in a steepened north-south surface salinity gradient in the Southern Ocean, which enhanced the upwelling. The single-forcing experiments indicate that the deglacial changes in orbital insolation influenced the Southern Ocean upwelling. The experiments also highlight the dominant role of Northern Hemisphere meltwater discharge in the upper and lower branch of the Meridional Overturning Circulation. Furthermore, orbital forcing shows lesser deglacial Antarctic sea ice retreat than the Northern Hemisphere meltwater forcing, which follows the bipolar seesaw mechanism.
\end{abstract}

Keywords: Southern Ocean upwelling; sea ice; windstress; orbital forcing; meltwater forcing; surface buoyancy forcing; freshwater flux; last deglaciation

\section{Introduction}

Numerous studies have shown that changes in orbital insolation played a significant role in driving the Earth's glacial-interglacial cycles [1-3]. For example, previous studies have suggested that an increase in mid-latitude to high-latitude Northern Hemisphere (NH) spring-summer insolation triggered the last deglaciation [3-6]. Consequently, the meltwater discharge from continental ice sheets retreat weakened the Atlantic Meridional Overturning Circulation (AMOC) [6] and caused the Southern Hemisphere (SH) deglacial warming via the bipolar seesaw mechanism [7-10]. The orbitally driven changes in NH insolation are also associated with increased Antarctic temperatures and atmospheric carbon dioxide concentrations during the last deglaciation [11]. Therefore, it is vital to understand the role of orbital forcing and its feedback in order to understand the Earth's climate.

The ocean has played a fundamental role in the Earth's climate system by absorbing, transporting, and releasing heat and carbon. The Southern Ocean (SO) (south of $30^{\circ} \mathrm{S}$ ) ventilates the deep ocean by exchanging heat and gases between the deep ocean and the atmosphere [12]. The deglacial period from 19 to $9 \mathrm{kyr}$ (thousand years) BP (before present) is punctuated by abrupt changes in SO ventilation [13-16], with about 75 parts per million by volume increase in atmospheric carbon dioxide concentrations $[17,18]$. Therefore, the SO has played a crucial role in controlling past atmospheric carbon dioxide concentrations [19]. 
Presently, the carbon storage in the deep ocean is approximately 60 times that in the atmosphere [20]. Consequently, even a small perturbation in the volume of $\mathrm{SO}$ upwelling may potentially alter atmospheric carbon dioxide concentrations [21,22].

The upper cell of the SO meridional overturning is understood to be primarily influenced by changes in strength and position of SH westerly winds $[13,15,23]$. The $\mathrm{SH}$ westerly windstress drives a northward horizontal Ekman transport (Eulerian meridional circulation). The divergence from surface Ekman transport overturns the ocean density surfaces to generate steepened density surfaces [24]. The carbon-rich deep ocean water upwells in nearly adiabatic pathways along these steeply tilted density surfaces towards the ocean surface around Antarctica [12]. However, the $\mathrm{SO}$ overturning, driven by the $\mathrm{SH}$ westerly wind, is partly compensated by mesoscale eddies $[25,26]$. Therefore, the residual $\mathrm{SO}$ overturning circulation is a sum of Eulerian-mean and eddy circulations [21].

The paleoclimate community accepts that the SO overturning circulation is primarily wind-driven $[13,15,23,27]$. Therefore, most of the studies explain the last deglacial evolution of the SO overturning circulation by the "westerlies shift" hypothesis. During interglacial (glacial) periods, a poleward (equatorward) migration of the SH subtropical westerly jet strengthened (weakened) the SO upwelling. As a result, it allowed more (less) respired carbon dioxide to outgas into the atmosphere and increased (decreased) the atmospheric carbon dioxide concentrations $[13,15,21,23,28-30]$.

Many paleo-proxies records (oceanic, pollen, dust, and lake level) [30-42] and climate model simulations [43-49] have independently studied the SH westerly winds shift during the Last Glacial Maximum ( $\approx 22$ to $19 \mathrm{kyr} \mathrm{BP})$. However, they show uncertainties in the position of the SH westerly winds. The modeling studies selected low-level westerly circulation at $850 \mathrm{hPa}$ to indicate the westerly-related storm track [44,45,50-52]. At $850 \mathrm{hPa}$, the boundary layer effects can substantially modulate the zonal winds before their impact reaches the surface of the SO [46]. In addition, the ocean surface windstress, instead of the nearsurface $850 \mathrm{hPa}$ winds, regulates the oceanic fronts and drives the SO upwelling [43,53-56]. Therefore, this study examines the changes in windstress to understand the evolution of SO upwelling. Moreover, several studies have also shown that changes in buoyancy flux by freshwater discharge $[12,24,57,58]$, ocean eddies [21,26], and topography [58,59] can explain the changes in the $\mathrm{SO}$ upwelling during the last deglaciation.

Antarctic sea ice plays a vital part in the global Meridional Overturning Circulation (MOC). It modifies globally widespread water masses through surface buoyancy gain (the region with lighter surface ocean density) and loss (the region with denser surface ocean density) [60]. The formation and melting of Antarctic sea ice alter surface buoyancy fluxes and modulate deep ocean stratification and MOC in the SO [22,24,57,58,61-67]. Studies have found that increased ocean stratification subsequently increases the deep-ocean carbon inventory and contributes to lower atmospheric carbon dioxide concentrations [60]. In addition, Antarctic sea ice coverage reduces the exposure time of surface waters with the atmosphere $[22,61]$ and air-sea gas exchange, enhancing deep ocean carbon sequestration [68]. Therefore, it is necessary to focus on the SH westerly windstress and the Antarctic sea ice distribution to understand the role of the $\mathrm{SO}$ in regulating atmospheric carbon dioxide concentrations.

The freshwater flux from the summertime melting of Antarctic sea ice contributes to SO surface buoyancy flux $[57,69,70]$. Thus, it is vital to understand the response of SO upwelling to a freshwater perturbation. The freshwater export increases the buoyancy of the upwelled circumpolar deep water [71], contributing to the closure of the upper branch of the overturning circulation in the $\mathrm{SO}[57,72]$. Buoyancy gain in the SO helps transform the deep returning flow into the intermediate and mode waters [60]. Conversely, wintertime formation of the Antarctic sea ice leads to buoyancy loss, which contributes to the lower branch of the MOC in the SO [12,73,74].

Thus, despite having a better understanding of the last deglacial SO dynamics, the role of deglacial orbital and meltwater climate forcings remains elusive. The authors of [75] showed that the SH orbital forcing changes, and Antarctic sea ice feedback influenced the 
SO climate during the last deglaciation. Recent studies have also highlighted the role of orbital forcing in wind-driven SO upwelling $[76,77]$. This modeling study investigates the response of orbital and meltwater climate forcings to the $\mathrm{SO}$ dynamics during the last deglacial period from 19 to $9 \mathrm{kyr}$ BP. Previous studies have indicated that local SO upwelling exhibits distinctive evolution patterns than the zonal mean SO upwelling during the last deglaciation [58]. This study examines the evolution of SO upwelling in the Atlantic Ocean basin to understand the MOC in the SO and North Atlantic. This contribution also focuses on the evolution of SO upwelling in response to Antarctic sea ice melt-induced freshwater fluxes using a fully coupled Earth system model during the last deglaciation. The conclusions support that the $\mathrm{SO}$ upwelling is influenced by orbital forcing and is primarily driven by SH windstress. The increase in Antarctic sea ice melt-induced freshwater export on the surface of the $\mathrm{SO}$ enhanced the $\mathrm{SO}$ upwelling during the last deglacial period.

\section{Materials and Methods}

\subsection{Data}

We analyzed annual data from the TraCE-21ka climate model for the last deglacial period. The TraCE-21ka is a fully coupled land surface-atmosphere (Community Atmospheric Model 3)-ocean (Parallel Ocean Program)-sea ice (Community Sea Ice Model) climate model experiment using the Community Climate System Model version 3 [78]. The model was forced with realistic transient variations in orbital insolation (Figure 1a), meltwater fluxes (Figure 1b), atmospheric greenhouse gas concentrations (Figure 1c), and retreating continental ice sheet (represented in eustatic sea level rise) (Figure 1c) boundary conditions during the last deglaciation. The TraCE-21ka data are available in the public domain (https:/ / www.earthsystemgrid.org/project/trace.html, last accessed on 1 December 2021).

The TraCE-21ka ice and ocean data have an identical resolution (gx3v5; about 3.6 degrees longitudinal and a variable latitudinal resolution to about 0.9 degrees near the equator). The ice and ocean data were interpolated to $\approx 3.75$ degrees resolution identical with the atmospheric data (T31). The ocean model has a vertical z coordinate with 25 depth levels and uses the ocean eddies parameterization [79]. In addition, the dynamic thermodynamic sea ice model incorporates a subgrid-scale ice thickness distribution.

We analyzed complete (FULL), orbital (ORB), and meltwater (MWF) single-forcing transient simulations for the last deglacial period. The focus was to investigate FULL, ORB, and MWF climate forcings' contribution to the upwelling and MOC in the SO. The experimental data analyzed are:

(1) FULL: a complete model simulation of the past $22 \mathrm{kyr}$ BP with transient alteration in orbital insolation, meltwater fluxes, continental ice sheets, and greenhouse gases. The continental ice sheet extents and orographies were adopted from the ICE-5G (VM2) [80].

(2) ORB: a single forcing transient simulation forced only by variations in orbital insolation. All other experimental boundary conditions were held constant with the values of $22 \mathrm{kyr}$ BP as in the FULL experiment.

(3) MWF: a single forcing transient simulation forced only by variations in $\mathrm{NH}$ meltwater fluxes similar to those applied in the FULL simulation. All other forcings were held constant with the values of $19 \mathrm{kyr} B \mathrm{P}$ as in the FULL experiment. 


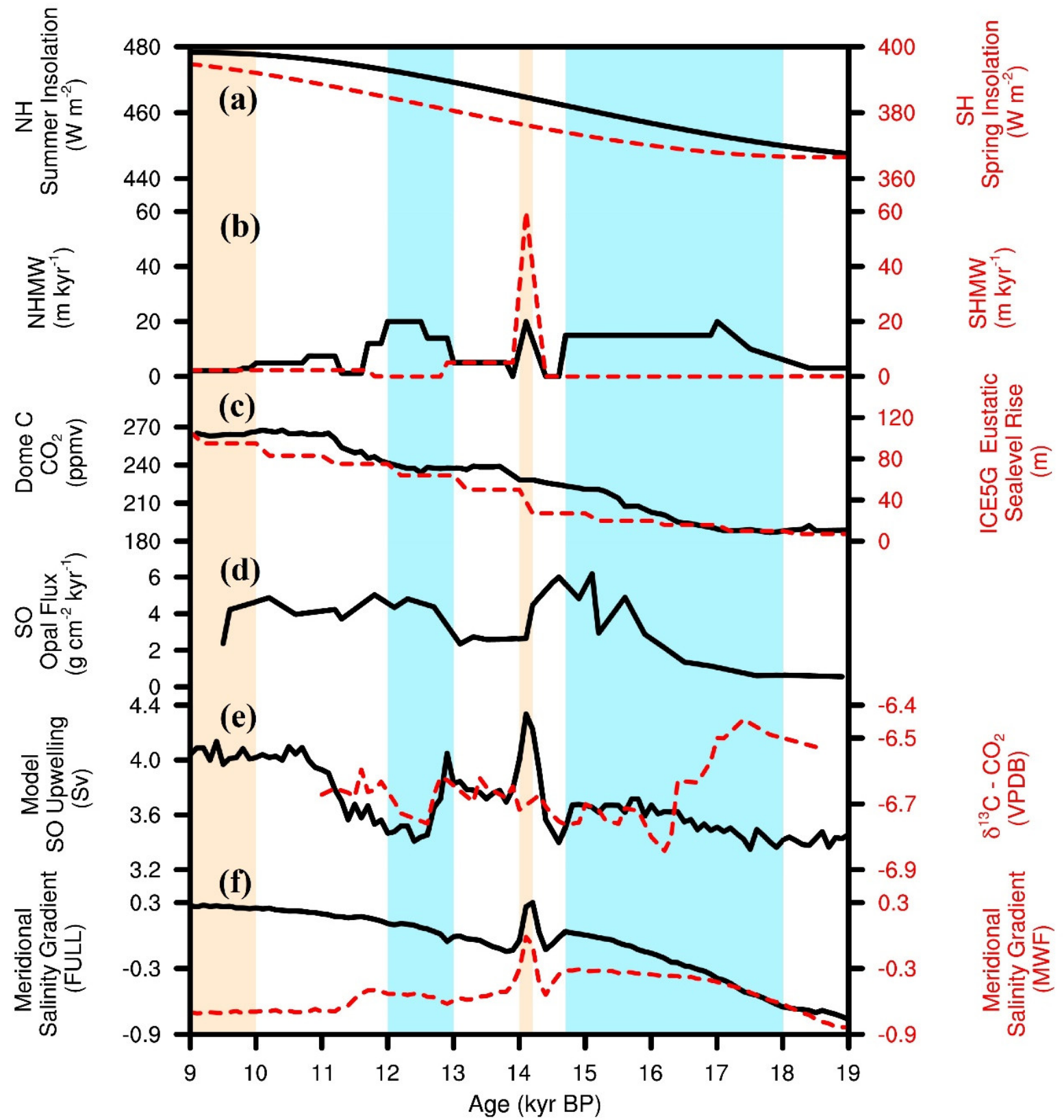

Figure 1. The TraCE-21ka model forcings and simulations during the last deglaciation. (a) The deglacial increase in the incoming solar insolation during the Northern Hemisphere (NH) summer $\left(30^{\circ} \mathrm{N}\right.$ to $\left.60^{\circ} \mathrm{N}\right)$ (solid black line) and the Southern Hemisphere $(\mathrm{SH})$ spring season $\left(30^{\circ} \mathrm{S}\right.$ to $\left.60^{\circ} \mathrm{S}\right)$ (red stippled line) (units are in Watt per meter square $\left(\mathrm{W} \mathrm{m}^{-2}\right)$ ). (b) The Northern Hemisphere (solid black line) and Southern Hemisphere (red stippled line) meltwater forcings (units are in meter per thousand years $\left(\mathrm{m} \mathrm{kyr}^{-1}\right)$ ) [78]. (c) The atmospheric carbon dioxide $\left(\mathrm{CO}_{2}\right)$ concentrations (solid black line) (units are in ppmv) [17] and the eustatic sea level change based on the ICE-5G (VM2) reconstruction (red stippled line) [80]. (d) The proxy record for the SO upwelling in the Atlantic Ocean basin; opal flux (solid black line) [13]. (e) The model simulated the SO upwelling (integrated upper $2000 \mathrm{~m}$ ) in the Atlantic Ocean sector (solid black line; units are in Sverdrup (Sv) ) and the carbon isotope $\delta^{13} \mathrm{C}-\mathrm{CO}_{2}$ records from the Taylor Glacier (red stippled line) [14]. (f) The TraCE$21 \mathrm{ka}$ simulated FULL (solid black line) and MWF (red stippled line) zonal meridional (north-south) salinity gradient between $30^{\circ} \mathrm{S}$ to $50^{\circ} \mathrm{S}$ and $50^{\circ} \mathrm{S}$ to $70^{\circ} \mathrm{S}$ above $70 \mathrm{~m}$ depth (signs are reversed). The shaded blue vertical bars represent Heinrich 1 (H1; $\approx 17.6$ to $14.7 \mathrm{kyr} \mathrm{BP})$ and the Younger Dryas (YD; $\approx 12.3$ to $11.6 \mathrm{kyr} \mathrm{BP})$ events. Additionally, the shaded red vertical bars represent meltwater pulse $1 \mathrm{~A}$ (mwp-1A) at about $14.1 \mathrm{kyr}$ BP and the onset of the Holocene (O_H; 10 to 9 kyr BP). 
From 22 to $19 \mathrm{kyr} \mathrm{BP}$, the continental ice sheet forcing was constant (no meltwater discharge), and the greenhouse gas concentrations forcing changed only slightly. The meltwater and ice single-forcing experiments branched off at 19 kyr BP from the FULL simulation. The TraCE-21ka simulated the 19 kyr BP event characterized by the eustatic sea level rise of about 10 to $15 \mathrm{~m}$ in about 100 to 500 years (Figure 1b) [81]. The model also simulated the meltwater pulse $1 \mathrm{~A}$ (mwp-1A) at about $14.1 \mathrm{kyr} \mathrm{BP}$, which caused the Allerød warm period ( $\approx 14$ to $12.9 \mathrm{kyr} \mathrm{BP})$. The mwp-1A is described by the sea level rise of about $20 \mathrm{~m}$ in about 300 to 500 years (Figure 1b) [82]. The author of [80] assigned the total $20 \mathrm{~m}$ sea level rise to $\mathrm{NH}$ origin, which set off an AMOC collapse in climate models [83]. However, several studies have included meltwater forcing contributions from the Antarctic (SH) (15 m of equivalent sea level volume) and Laurentide Ice Sheets (NH) (5 $\mathrm{m}$ of equivalent sea level volume) $[84,85]$. Studies have also shown that a NH meltwater forcing of more than $5 \mathrm{~m}$ resulted in a complete shutdown of AMOC, which is inconsistent with proxy records [86]. Therefore, the TraCE-21ka adopted the SH (Antarctic) meltwater forcing (60 Sverdrup (Sv); $1 \mathrm{~Sv}=10^{6} \mathrm{~m}^{3} \mathrm{~s}^{-1}$ ) and the NH meltwater forcing (20 Sv) during the mwp-1A. This meltwater discharge was added as a freshwater flux to the ocean model onto the ocean surface.

\subsection{Model Performance}

Numerous studies of the last deglacial period have shown that the TraCE-21ka model reproduced several critical features of the global climate evolution [78,87]. For example, the TraCE-21ka model replicated the Asian-African monsoon [88], El Niño [89], the highlatitude seasonal temperature [90], the AMOC transport, and the SH regional sea surface temperature [5]. In addition, the model reasonably simulated the present-day atmospheric circulation and sea surface temperature in the SO $[49,91]$.

We performed a comprehensive data-model comparison between proxy records (Figure 1d,e) and the TraCE-21ka FULL simulation upwelling in the Atlantic Ocean sector of the SO during the last deglacial period (Figure 1e). The TraCE-21ka model simulated an increase in SO upwelling during the Heinrich $1(\mathrm{H} 1)$ and the latter part of the Younger Dryas (YD) events in agreement with numerical simulations [15] and proxy records (Figure 1d,e) $[13,14,18,92]$. The simulation demonstrated a gradual increase in SO upwelling during the early part of deglaciation, agreeing with the proxy record [13]. As such, it did not replicate the abrupt increase around $16.3 \mathrm{kyr} \mathrm{BP}$, as shown by proxy record [14] and numerical simulations [15]. We found that the simulated SO upwelling followed the high precision, century-scale proxy record from [14] reasonably well (Figure 1e). The model simulation considerably overlapped with the century-scale changes in $\delta^{13} \mathrm{C}-\mathrm{CO}_{2}$ proxy marine source records at $12.9 \mathrm{kyr} \mathrm{BP}$, indicating strengthened air-sea gas exchange in the SO [14]. The simulation also showed an increase in the SO upwelling around 17 to $16 \mathrm{kyr}$ $\mathrm{BP}$ associated with increased atmospheric carbon dioxide concentrations, evident from the proxy record [18] and numerical simulations [15]. Additionally, the authors of [58] employed the TraCE-21ka model and simulated SO upwelling at corresponding grids of proxy cores in the SO $[13,93]$. Their simulation also followed the proxy records, with some alterations in the magnitude and timing of the deglacial upwelling changes. In conclusion, the TraCE-21ka model performed reasonably well in simulating the changes in the SO upwelling during the last deglacial period.

Like most global ocean models, the TraCE-21ka model did not simulate the eddy effect. Instead, the ocean model used the Gent and McWilliams eddy parameterization [79] to approximate the eddy-induced vertical velocity response to surface forcings. Thus, the TraCE-21ka model produced an Eulerian-mean meridional overturning circulation. Nevertheless, it performed reasonably well in representing the deglacial SO upwelling due to a significant contribution from Eulerian-mean upwelling to tracer movements. 


\subsection{Methodology}

The authors of [58] employed the TraCE-21ka model and found that the zonal mean upwelling from vertical ocean velocity equals the zonal mean Ekman pumping in the upper $2000 \mathrm{~m}$ in the SO. This study diagnosed the TraCE-21ka data and integrated the upper 2000 $\mathrm{m}$ of vertical ocean velocity to calculate the SO upwelling volume in the Atlantic Ocean basin during the deglacial period, as shown in Equation (1).

$$
\hat{\mathrm{W}}=\frac{\sum_{\mathrm{k=1}}^{\mathrm{N}} \mathrm{w}(\mathrm{k}) \mathrm{dz}(\mathrm{k})}{\sum_{\mathrm{k}=1}^{\mathrm{N}} \mathrm{dz}(\mathrm{k})}
$$

where $\hat{\mathrm{W}}$ is the integrated upwelling along with the depth, $\mathrm{w}(\mathrm{k})$ is the vertical velocity at each ocean grid, $\mathrm{dz}(\mathrm{k})$ is the thickness of the kth level, and $\mathrm{N}$ is the number of vertical ocean grids. We also analyzed the integrated upwelling for the upper $500 \mathrm{~m}$ of the SO. Similar conclusions were drawn from the study despite a change in depth of the representative sector.

This study examined the time evolution of the SO upwelling through the last deglacial period from 19 to $9 \mathrm{kyr}$ BP. It included the $19 \mathrm{kyr} \mathrm{BP}$, the H1, and the YD events. We selected two millennial timescales: (1) the Heinrich 1 (H1; from 17.3 to $16.3 \mathrm{kyr} \mathrm{BP}$ ), and (2) the onset of the Holocene (O_H; from 10 to $9 \mathrm{kyr} \mathrm{BP})$, to highlight early and later parts of the deglaciation.

\section{Results}

\subsection{Southern Ocean Dynamics}

We analyzed the TraCE-21ka complete (FULL) and single forcing orbital (ORB) and meltwater (MWF) simulations during the last deglaciation to understand the evolution of the MOC. Figure 2a illustrates that the TraCE-21ka FULL experiment indicated a weakened upper overturning cell during the early from the later part of deglaciation. It also shows a more robust and extended lower overturning cell during the early part compared to the later part of the deglaciation (see Supplementary Figure S1). We found that only the MWF experiment shows weakened AMOC similar to the FULL experiment during the early part of the deglaciation (Figure $2 b, c$ ).

(a) FULL: $\mathrm{H} 1$ - O_H

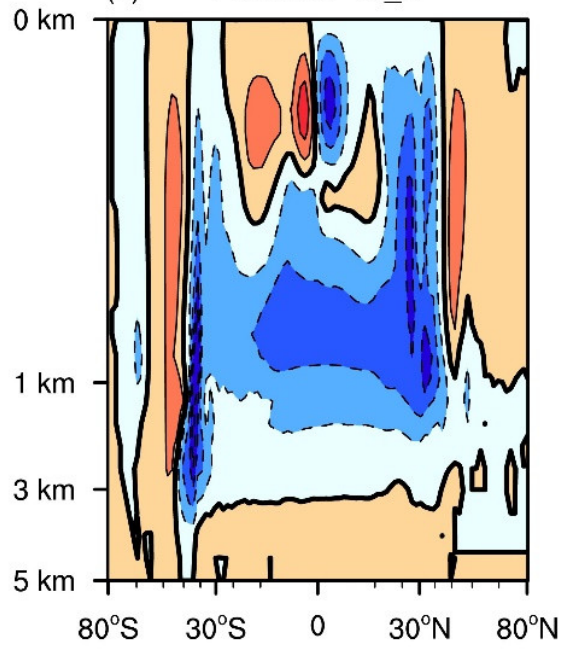

(b)

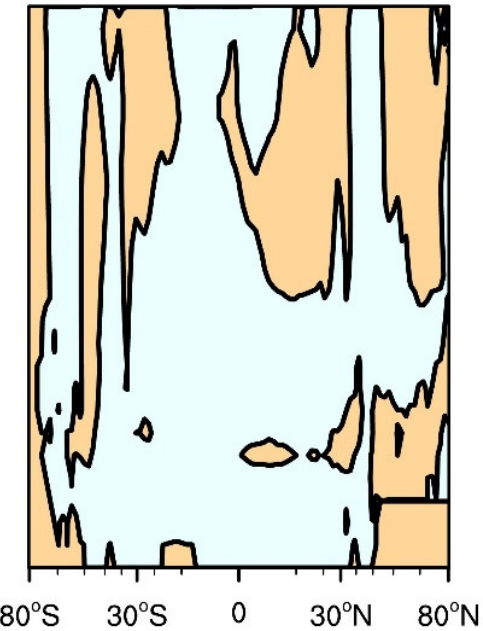

(c) MWF: $\mathrm{H} 1$ - O_H

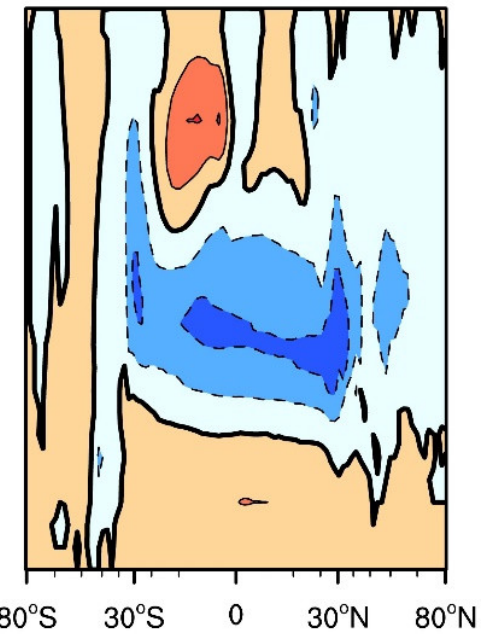

Figure 2. The characteristics of deglacial change in meridional overturning circulation (MOC) between the Heinrich 1 (H1) and the onset of the Holocene $\left(\mathrm{O} \_\mathrm{H}\right)$ in (a) the full forcing (FULL), (b) the orbital forcing (ORB), and (c) the meltwater forcing (MWF) experiments. The units are in Sverdrup (Sv). 
The FULL experiment reasonably simulated the decrease in AMOC transport during the last deglaciation, which is consistent with the AMOC export proxy record (Figure 3a). We found that the simulated strength of upper overturning circulation during the H1 was about $57 \%$ weaker than during the O_H (Table 1 ). Conversely, the simulated maximum strength of the lower overturning circulation during the $\mathrm{H} 1$ was about $12 \%$ stronger than it was during the $\mathrm{O} \_\mathrm{H}$ (Figure $3 \mathrm{~b}$ ) (Table 1).

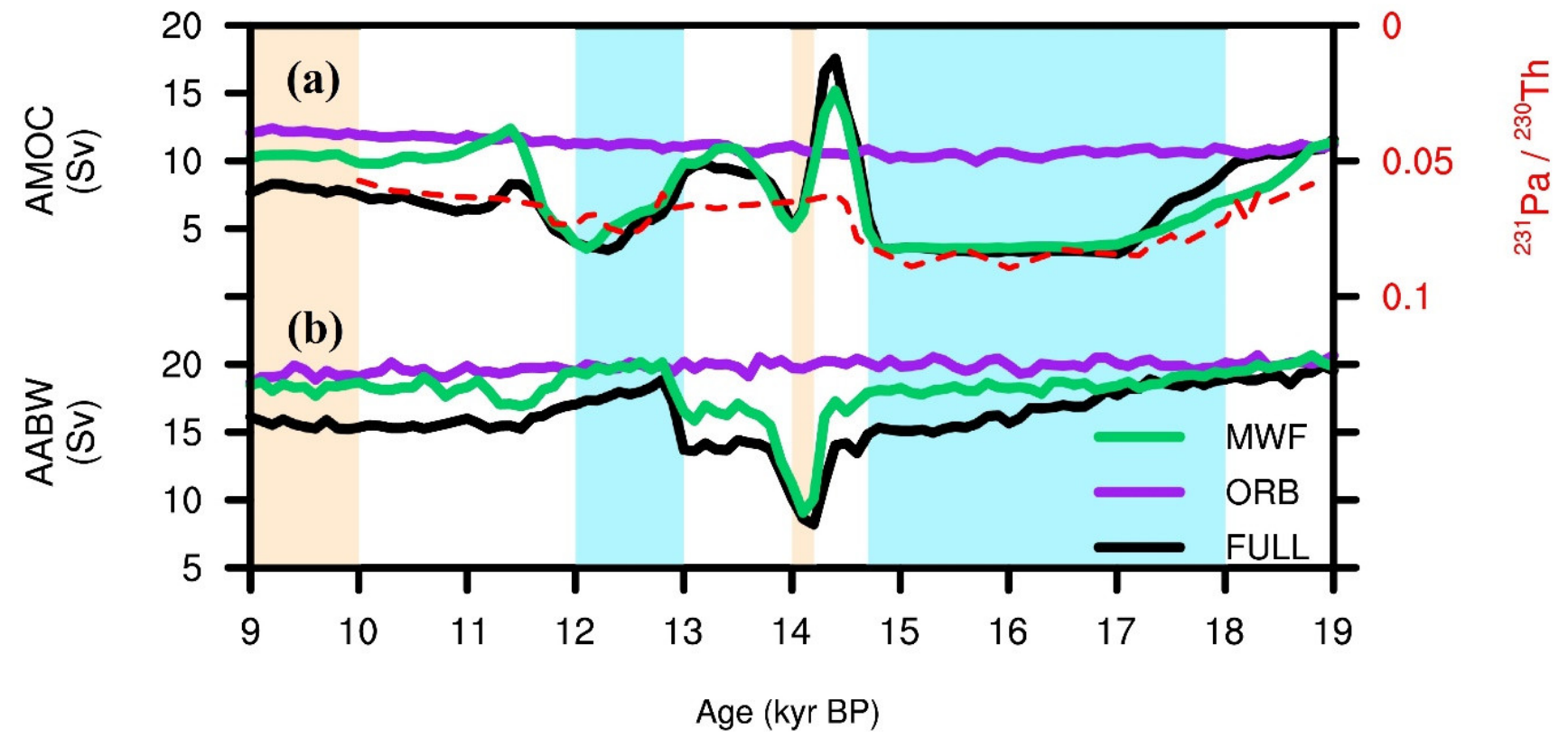

Figure 3. The simulated upper (AMOC; waters of North Atlantic origin) and lower (Antarctic Bottom Water and its derivatives) MOC transport in full (FULL; black color), orbital (ORB; purple color), and meltwater (MWF; green color) forcing experiments during the last deglaciation. (a) The TraCE-21ka simulated AMOC transport (solid lines; units are in Sverdrup (Sv)) and the proxy for AMOC export $\left({ }^{231} \mathrm{~Pa} /{ }^{230} \mathrm{Th}\right.$ ratio) (red stippled line) [86]. (b) The simulated maximum strength of the lower MOC branch transporting Antarctic Bottom Water and its derivatives (solid lines; units are in Sverdrup (Sv)). The shaded blue vertical bars represent Heinrich 1 and the Younger Dryas events. Additionally, the shaded red vertical bars represent meltwater pulse $1 \mathrm{~A}$ and the onset of the Holocene.

Table 1. Description of the MOC transport. The AMOC transport was the maximum transport below a $500 \mathrm{~m}$ ocean depth. The maximum lower MOC transport was the maximum transport below a $1.3 \mathrm{~km}$ ocean depth. Its units are in Sverdrup (Sv).

\begin{tabular}{ccc}
\hline Transport $(S \boldsymbol{v})$ & H1 & O_H \\
\hline AMOC & 5 & 8 \\
Maximum lower MOC & 17.6 & 15.5 \\
\hline
\end{tabular}

We found that the MWF experiment reasonably reproduced the strength of upper and lower overturning circulation compared to the ORB experiment during the last deglaciation (Figure 3a,b). The MWF experiment simulated strength of upper (Figure 3a) and lower (Figure $3 b$ ) overturning circulation has an excellent agreement with the FULL experiment during the early $((\mathrm{r}=1, p<0.001)$ and $(\mathrm{r}=0.7, p<0.001))$ and late $((\mathrm{r}=0.9, p<0.001)$ and $(\mathrm{r}=0.8, p<0.001))$ parts of the deglaciation, respectively. 
Figure $4 \mathrm{a}$ indicates that the ORB experiment simulated maximum $\mathrm{SO}$ upwelling (the scale is on the right $y$-axis) agrees with the FULL experiment (the scale is on the left $y$-axis) reasonably well during the early (decrease) and late (increase) parts of the deglaciation. Specifically, the ORB experiment has a Pearson correlation coefficient of $0.4(p<0.01)$ during the early (19 to $14.7 \mathrm{kyr} \mathrm{BP}$ ) and late (14.7 to $12.4 \mathrm{kyr} \mathrm{BP}$ ) parts of deglaciation. On the contrary, the MWF experiment (the scale is on the left $y$-axis) indicated that the SO upwelling followed the FULL experiment only during the middle (14.7 to $12.4 \mathrm{kyr} \mathrm{BP}$ ) part of the deglaciation $(\mathrm{r}=0.5 ; p<0.001)$, as shown in Figure $4 \mathrm{a}$.

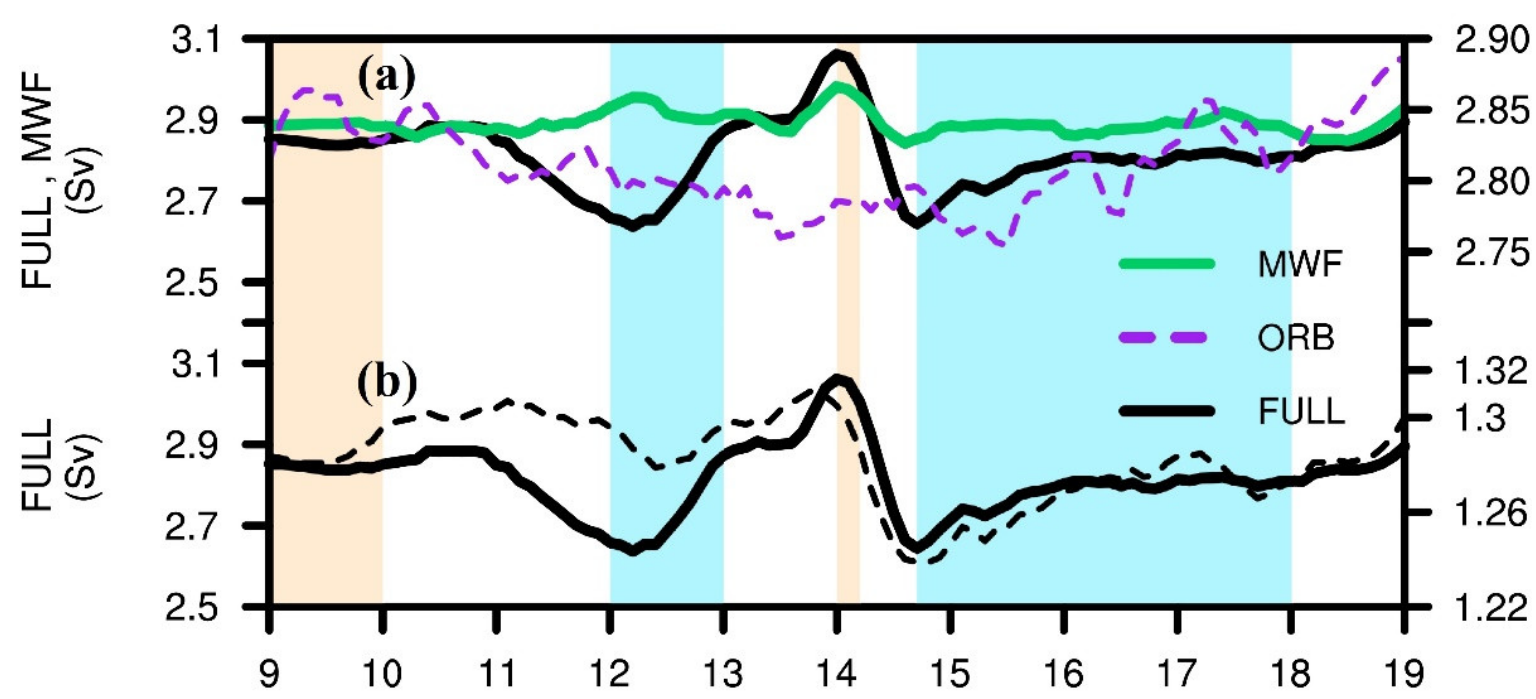

Age (kyr BP)

Figure 4. The TraCE-21ka simulated SO upwelling in the FULL (black color), single-forcing ORB (purple color), and single-forcing MWF (green color) experiments, and the FULL (black color) SH zonal windstress smoothed using a Savitsky-Golay filter with a third-order polynomial convolution. We calculated the SO upwelling (integrated upper $2000 \mathrm{~m}$ ) in the Atlantic Ocean sector, which overlaps with the maximum ocean vertical velocity zone $\left(\approx 53^{\circ} \mathrm{S}\right.$ to $\left.61^{\circ} \mathrm{S}\right)$. (a) The model simulated deglacial SO upwelling in the ORB (stippled line; units are in Sverdrup) experiment (the scale is on the right $y$-axis). It also shows the deglacial SO upwelling in the FULL (solid line; units are in Sverdrup (Sv) ) and the MWF (solid line; units are in Sverdrup) experiments (the scales are on the left $y$-axis). (b) The FULL SH zonal average windstress $\left(\approx 43^{\circ} \mathrm{S}\right.$ to $\left.61^{\circ} \mathrm{S}\right)$ (black stippled line, units are in dyne per square centimeter (dyne $\left.\mathrm{cm}^{-2}\right)$ ) (the scale is on the right $y$-axis). It also shows the simulated deglacial SO upwelling in the FULL (solid line; units are in Sverdrup (Sv) ) experiment (the scale is on the left $y$-axis) during the last deglaciation. The shaded blue vertical bars represent Heinrich 1 and the Younger Dryas events. Additionally, the shaded red vertical bars represent meltwater pulse 1A and the onset of the Holocene.

The FULL experiment demonstrated that the evolution of the SO upwelling followed the changes in $\mathrm{SH}$ windstress reasonably well throughout the last deglaciation (Figure $4 \mathrm{~b}$ ). We found that the simulated SO upwelling and zonal windstress has a Pearson correlation coefficient of $0.6(p<0.001)$ during the last deglacial period (19 to $9 \mathrm{kyr}$ BP). Specifically, it has a Pearson correlation coefficient of $0.9(p=0)$ during the early, $0.7(p<0.001)$ during the middle, and $0.4(p<0.001)$ during the late parts of the deglaciation. Additionally, the ORB experiment demonstrated a Pearson correlation coefficient of $0.8(p<0.001)$ between SO upwelling and zonal windstress during the last deglacial period. 


\subsection{Antarctic Sea Ice Dynamics}

The FULL experiment simulated a decrease in Antarctic sea ice coverage during the last deglacial period (Figure 5 and Figure S2a). The FULL and the MWF experiments demonstrated a steep decrease in Antarctic sea ice coverage during the H1, the YD events, and an abrupt increase during the Antarctic Cold Reversal (ACR; $\approx 14.5$ to $\approx 12.5 \mathrm{kyr} \mathrm{BP}$ ) period. On the other hand, the ORB experiment simulated an extended deglacial Antarctic sea ice coverage which gradually decreased during the last deglacial period. The ORB experiment showed reduced coverage of the Antarctic sea ice in the Indian and the Pacific sectors of the SO (Supplementary Figure S2b). However, the MWF experiment showed similar Antarctic sea ice coverage between the early and late parts of the deglaciation (Supplementary Figure S2c).

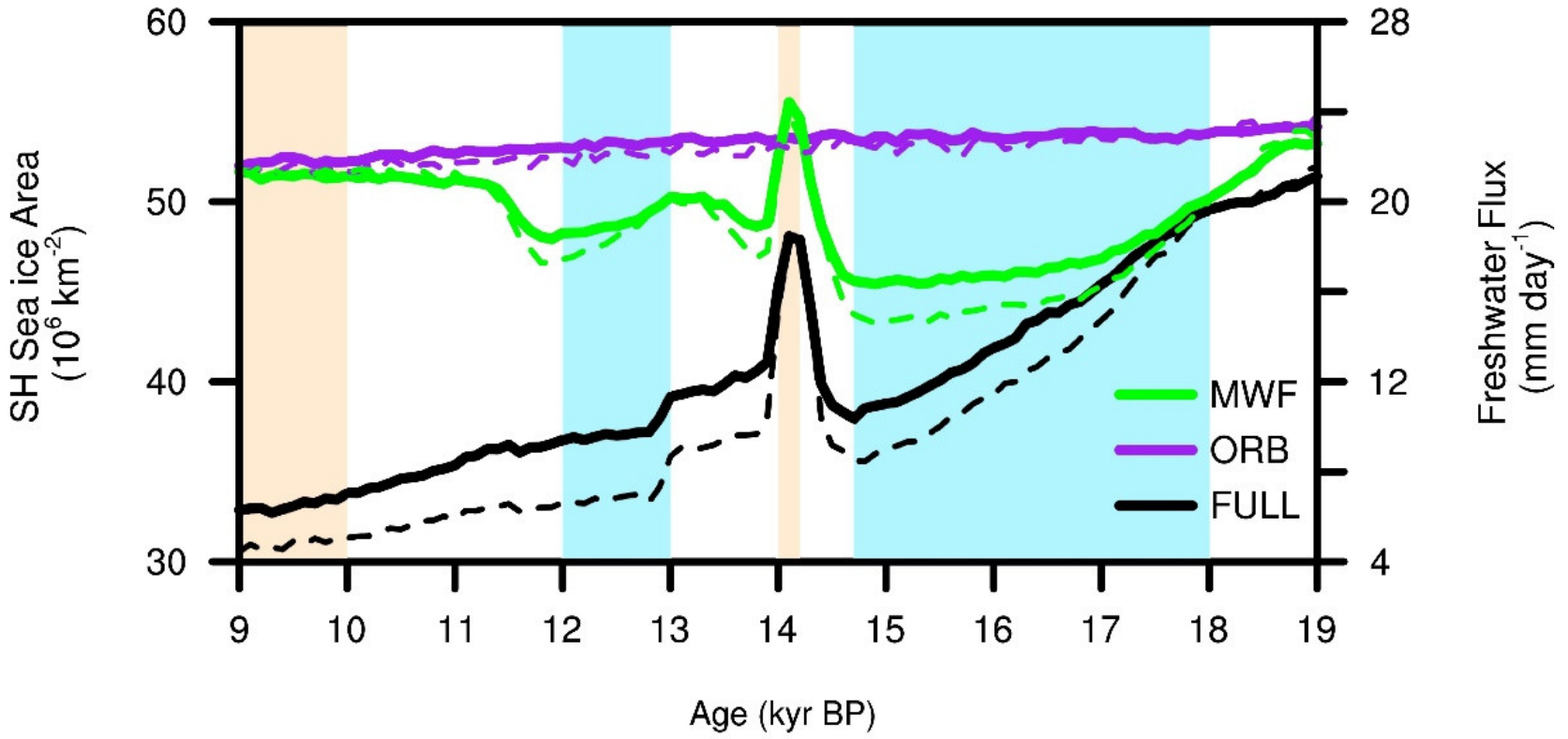

Figure 5. The TraCE-21ka simulated coverage of the Southern Hemisphere sea ice (solid lines, units are in a million square kilometers $\left.\left(10^{6} \mathrm{~km}^{-2}\right)\right)$ and freshwater discharge from Antarctic sea ice melt $\left(\approx 50^{\circ} \mathrm{S}\right)$ (stippled lines, units are in a millimeter per day $\left.\left(\mathrm{mm} \mathrm{day}^{-1}\right)\right)$ in the FULL (black color), the ORB (purple color), and the MWF (green color) experiments during the last deglaciation. The shaded blue vertical bars represent Heinrich 1 and the Younger Dryas events. Additionally, the shaded red vertical bars represent meltwater pulse $1 \mathrm{~A}$ and the onset of the Holocene.

Figure 6 shows the decrease in the Antarctic quasi-permanent sea ice coverage (SO surface area covered with more than eighty percent sea ice fraction) in the FULL experiment during the last deglacial period. The SO region with negative surface buoyancy flux (denser surface ocean density) was also displaced towards Antarctica during the last deglacial period. Additionally, Figure 6 highlights that the Antarctic quasi-permanent sea ice boundary overlaps with the transition of surface buoyancy flux from positive (surface buoyancy gain) to negative (surface buoyancy loss) during the last deglacial period. 
a) $\mathrm{H} 1$

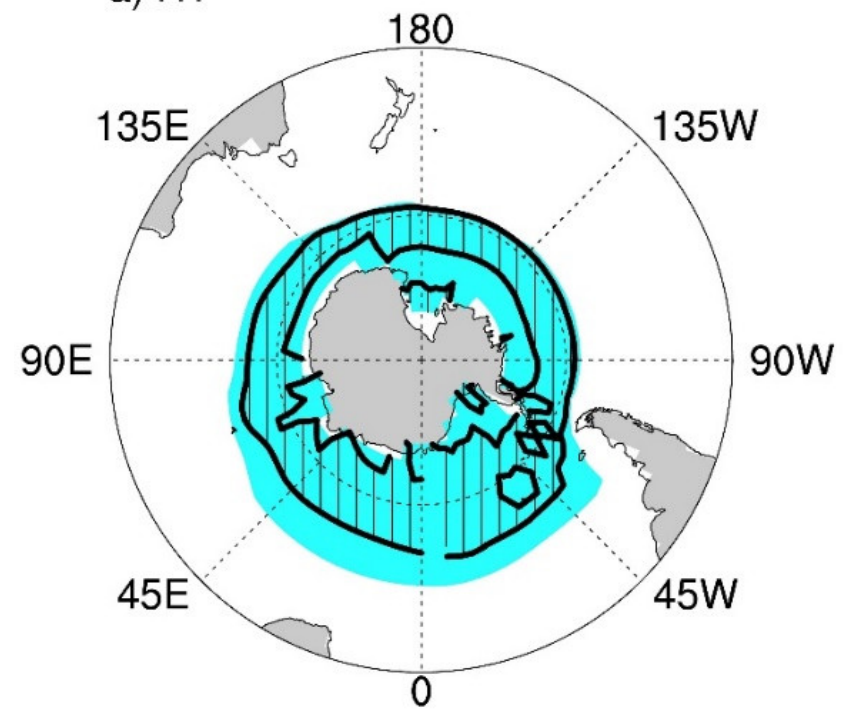

b) $\mathrm{O} \_\mathrm{H}$

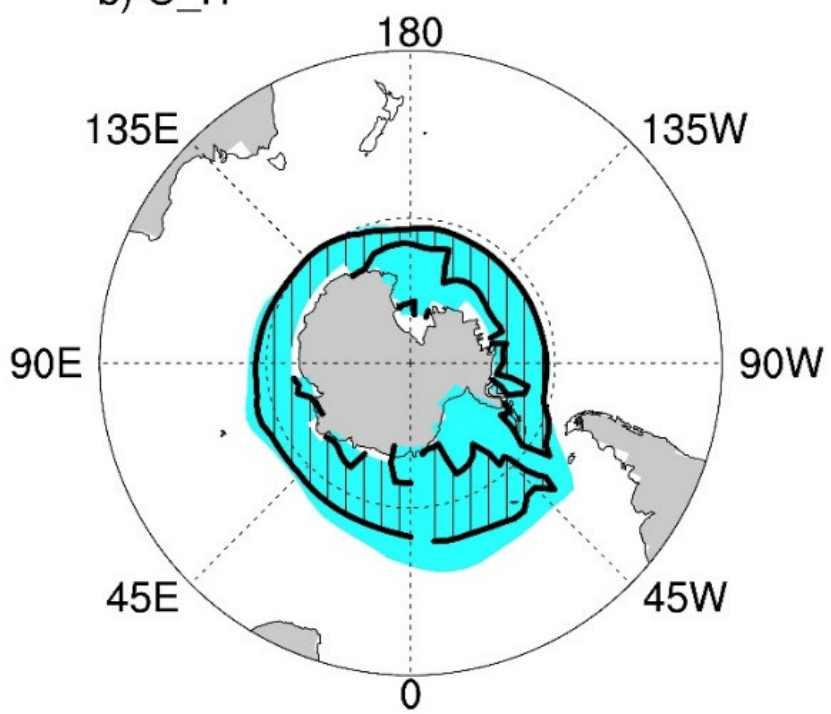

Figure 6. The Southern Hemisphere quasi-permanent (more than eighty percent sea ice fraction) sea ice coverage (shaded in blue color; units are in a fraction) overlying the buoyancy loss zone (negative surface buoyancy flux shown in a black shaded pattern) during (a) the Heinrich 1 (H1) and (b) the onset of the Holocene (O_H).

\section{Discussion}

This study examined the deglacial evolution of the SO upwelling in the Atlantic Ocean basin to understand the $\mathrm{SO}$ dynamics employing a fully coupled climate model simulation, the TraCE-21ka. Numerous studies have suggested that the SO upwelling is primarily wind-driven $[12,13,15,23,94]$. The authors of [23] proposed the "westerlies shift" hypothesis, wherein a poleward (equatorward) shift or an increase (decrease) in SH westerlies increased (decreased) the wind-driven $\mathrm{SO}$ upwelling. As a result, it allowed more (less) respired carbon dioxide to outgas into the atmosphere. Recently, the authors of [49] showed that the TraCE-21ka model simulated the deglacial shift of the SH westerly jet in agreement with the "westerlies shift" hypothesis. Moreover, the authors of [58] also employed the TraCE-21ka model and found that the local SO upwelling is driven by surface wind stress and surface buoyancy forcing and is influenced by the local topography. This work studied the basin-scale SO upwelling in the Atlantic Ocean sector during the last deglacial period instead of local upwelling. We found that the changes in the $\mathrm{SO}$ upwelling reasonably agreed with the proxies and numerical simulations and are driven by surface windstress and Antarctic sea ice-influenced surface buoyancy forcing.

The Antarctic sea ice played a pivotal role in the MOC by modifying water masses globally [60]. The Antarctic sea ice-ocean feedback included wintertime sea ice formation (brine rejection), which left salt content, and included summertime melting, which returned liquid freshwater to the ocean. This feedback altered surface buoyancy fluxes and modulated SO deep ocean stratification and overturning circulation $[22,24,57,58,61-66,69,70,95]$. The TraCE-21ka FULL experiment indicated a deglacial decrease in Antarctic sea ice coverage in good agreement with the proxy records [96]. This study demonstrated that, during the last deglacial period, the boundary of SO surface area covered with sea ice most of the year overlapped with the transition of surface buoyancy flux (positive (gain) to negative (loss)). The authors of [61] showed a similar relationship between the Antarctic quasi-permanent sea ice and surface buoyancy flux in the present-day and the Last Glacial Maximum climate. However, this study highlighted the association between the Antarctic sea ice coverage and the surface buoyancy forcing during the last deglacial period. Our results suggested that, during the last deglaciation, an increase (decrease) in the Antarctic sea ice extent corresponds to an increase (decrease) in the coverage of the buoyancy loss zone. Recent 
studies have also indicated that a shift in the Antarctic sea ice extent caused a change in the extent of surface buoyancy flux $[21,61,62,97]$.

Previous studies have indicated that the SO surface buoyancy forcing was dominated by changes in freshwater export [70] associated with summertime melting of Antarctic sea ice $[22,57,69]$. The authors of [57] estimated the recent (2005 to 2010) bulk freshwater volume fluxes at the SO surface south of $50^{\circ} \mathrm{S}$ from ocean and ice observations. They showed that the net volume of freshwater fluxes from the Antarctic sea ice melt was almost ten times more than that of the glacial ice melt [57]. Additionally, the authors of [58] employed the TraCE-21ka model and showed that changes in surface SO freshwater fluxes were essentially contributed by Antarctic sea ice melt and brine rejection during the last deglaciation. Thus, present-day studies and last deglacial studies highlight that the freshwater discharge from Antarctic sea ice melt is vital to understanding SO dynamics.

This study analyzed the zonal freshwater flux in the SO at the boundary of the quasipermanent sea ice and buoyancy flux transition $\left(\approx 50^{\circ} \mathrm{S}\right)$. We found that the simulated freshwater discharge closely followed the Antarctic sea ice coverage in all the experiments during the last deglacial period (Figure 5). In addition, the FULL and the MWF experiments showed maximum upwelling (Figure 4a) and enhanced Antarctic sea ice coverage (Figure 5) at about $14.1 \mathrm{kyr} \mathrm{BP}$ that coincided with the mwp-1A.

The FULL experiment simulated the mwp- $1 \mathrm{~A}$, which consisted of the $\mathrm{NH}$ and the $\mathrm{SH}$ meltwater forcings (Figure 1b). The meltwater discharge was added as a freshwater flux onto the ocean surface in the ocean model. The simulated freshwater flux from the $\mathrm{SH}$ meltwater forcing is three times the magnitude of the NH meltwater forcing (Figure 1b). On the other hand, the MWF experiment simulated the mwp-1A with only the NH meltwater discharge being similar in magnitude to that of the FULL experiment. At $14.1 \mathrm{kyr} B P$, we found that the surface north-south salinity gradient in the FULL experiment is about thirty times the MWF experiment in the SO (Figure 1f). Thus, this increased freshwater flux into the $\mathrm{SO}$ area via the $\mathrm{SH}$ meltwater forcing enhanced the $\mathrm{SO}$ upwelling. Previous studies have also shown that freshwater export from the Antarctic sea ice melt increased the buoyancy of the upwelled SO Circumpolar Deep Water [71]. Consequently, it strengthened the upper branch of the MOC $[57,72]$. Therefore, this study shows that freshwater discharge to the north and brine rejection to the south of the quasi-permanent Antarctic sea ice boundary steepened the surface north-south salinity gradient, as shown in Figure 1f (signs are reversed). As a result, it strengthened the overturning circulation in the SO.

During the $\mathrm{H} 1$ and the YD events, the NH meltwater discharge weakened the AMOC (Figure 3a). As a result, the bipolar seesaw [7-9] feedback resulted in deep-ocean warming, increased SH surface air temperature, and Antarctic sea ice retreat $[5,78]$. However, the AMOC resumed during the ACR, and the bipolar seesaw feedback resulted in the extension of Antarctic sea ice (Figure 5). In addition, previous experiments have indicated that the rise in austral spring insolation increased the absorption of the incoming shortwave radiation during the last deglaciation. As a result, it warmed the surface-air temperature and further reduced the Antarctic sea ice coverage [75].

The NH summer and the SH spring insolation in the FULL and the ORB experiments increased during the last deglacial period (Figure 1a). The TraCE-21ka FULL and sensitivity experiments indicated that orbital forcing contributed to the deglacial decrease in Antarctic sea ice coverage, as suggested by earlier experiments [98]. However, this study found that the orbital forcing resulted in a relatively milder Antarctic sea ice retreat than the $\mathrm{NH}$ meltwater forcing. On the other hand, the NH meltwater forcing showed Antarctic sea ice retreat corresponding to the bipolar seesaw mechanism. Therefore, the TraCE-21ka single-forcing experiments indicated that the combined effect of Northern Hemisphere meltwater flux, increase in insolation and greenhouse gasses, and lowering continental ice sheets could explain the Antarctic sea ice coverage during the last deglacial period.

Recent studies have highlighted that orbital forcing played a substantial role in the changes in $\mathrm{AMOC}$, SO windstress, and $\mathrm{SO}$ ventilation during the last deglaciation [76]. Additionally, the authors of [77] provided evidence of orbital-scale changes in the wind-driven 
SO upwelling. This study shows that the ORB experiment followed the FULL experiment simulated SO upwelling. The ORB experiment also showed a strong correlation between SO upwelling and zonal windstress throughout the last deglacial period. Furthermore, the freshwater discharge from ORB experiment simulated Antarctic sea ice modulated the north-south salinity gradient in the surface of the SO. Thus, this study highlights a significant association of orbital forcing with the evolution of the $\mathrm{SO}$ upwelling during the last deglacial period.

\section{Conclusions}

The TraCE-21ka ocean model used the eddy parameterization, as it could not resolve eddies. However, we showed that the depth-integrated Eulerian mean upwelling reasonably showed that the deglacial changes in the Southern Ocean upwelling were in agreement with proxy records and numerical simulations. In addition, our results show that the TraCE-21ka simulations agreed with the wind-driven Southern Ocean upwelling hypothesis.

We found that the Northern Hemisphere meltwater discharge contributed to the strength of the upper (AMOC) and lower (Antarctic Bottom Water and its derivatives) branch of the Meridional Overturning Circulation in the Southern Ocean. The meltwater experiment also showed the Antarctic sea ice coverage in response to the bipolar seesaw mechanism compared to a gradual decrease by the orbital experiment throughout the deglacial period. However, the TraCE-21ka orbital experiment, instead of the meltwater experiment, simulated the evolution of the Southern Ocean upwelling reasonably well during the last deglacial period. The orbital experiment also showed a strong correlation between the deglacial Southern Ocean windstress and upwelling, emphasizing the role of wind in Southern Ocean upwelling. Unfortunately, due to data availability, we could not study the seasonal change in the Southern Ocean upwelling. Moreover, it is worth noting that changing continental ice sheets and increasing greenhouse gasses may also contribute to the Southern Ocean dynamics.

Our results show that the coverage of Antarctic quasi-permanent sea ice (Southern Ocean surface area covered with more than eighty percent sea ice) overlapped with the buoyancy loss zone. Thus, a shift in the extent of the deglacial Antarctic sea ice can change the coverage of the surface buoyancy flux. Our results also indicate that Antarctic sea ice and associated surface freshwater discharge played a crucial part in modulating the Southern Ocean upwelling during the last deglaciation.

We found that increased freshwater flux on the surface of the Southern Ocean increased the north-south surface salinity gradient and enhanced the Southern Ocean upwelling. Our study helps understand the physical mechanisms that controlled the Southern Ocean dynamics. The physical mechanisms discussed in our manuscript hold in present-day Southern Ocean dynamics. Presently, we are experiencing ocean warming and Antarctic sea ice melt-induced freshening of the Antarctic shelf waters in response to global warming. Recent studies have also shown that salinity $[99,100]$ and Antarctic meltwater [101] changes in the Southern Ocean. Thus, it is vital to understand the role of freshwater discharge in the Southern Ocean to understand present-day and future climate projections. Our study helps understand the role of freshwater discharge in the Southern Ocean and provides prospects for further scientific development. Thus, our manuscript is vital to understand the physical mechanisms that contribute to the Southern Ocean processes, which can help to understand present-day and future changes. It has to be considered that the impact of changes in the Southern Ocean upwelling cannot precisely explain the variations in atmospheric carbon dioxide concentrations. Besides the Southern Ocean upwelling changes, many other processes and mechanisms, such as ocean biological pump, vertical mixing, properties of the upwelling water, ocean warming, and weathering, can contribute to the deglacial changes in atmospheric carbon dioxide concentrations. 
Supplementary Materials: The following are available online at https: / / www.mdpi.com/article/ 10.3390/su14052927/s1: Figure S1: The upper and lower meridional overturning cells during the Heinrich 1 and the onset of the Holocene; Figure S2: The Antarctic sea ice coverage between the Heinrich 1 and the onset of the Holocene; Table S1: The meridional salinity gradient at $14.1 \mathrm{kyr}$ BP in the FULL and the MWF experiments.

Author Contributions: Conceptualization: G.M. and S.-Y.L.; methodology: G.M. and S.-Y.L.; validation: G.M.; formal analysis: G.M.; investigation: G.M.; resources: S.-Y.L.; data curation, G.M. and S.-Y.L.; writing—original draft preparation: G.M.; writing—review and editing: G.M., S.-Y.L. and J.-Y.Y.; visualization: G.M.; supervision: S.-Y.L. and J.-Y.Y.; project administration: S.-Y.L.; funding acquisition: S.-Y.L. and G.M. All authors have read and agreed to the published version of the manuscript.

Funding: The Ministry of Science and Technology of Taiwan (MOST) provided grants \#104-2611-M-001001-, \#105-2611-M-001-002-, and \#106-2628-M-002-013- to Gagan Mandal and Shih-Yu Lee. Academia Sinica awarded the Taiwan International Graduate Program (TIGP) scholarship to Gagan Mandal.

Institutional Review Board Statement: Not applicable.

Informed Consent Statement: Not applicable.

Data Availability Statement: The TraCE-21ka data are available in the public domain (https:/ /www. earthsystemgrid.org/project/trace.html). Last accessed on 1 December 2021.

Acknowledgments: We are grateful to the group that was behind the TraCE-21ka experiments and that publicly shared the model output through the National Center for Atmospheric Research Climate Data Gateway. We thank Suranjith Bandara Koralegedara, Balaji Kumar Seela, Amali Hettiarachchi, Utpal Kumar, and A.S. Mohammed Abdul Athick for their valuable discussions.

Conflicts of Interest: The authors declare no conflict of interest.

\section{References}

1. Abe-Ouchi, A.; Saito, F.; Kawamura, K.; Raymo, M.E.; Okuno, J.; Takahashi, K.; Blatter, H. Insolation-driven 100,000-year glacial cycles and hysteresis of ice-sheet volume. Nature 2013, 500, 190-193. [CrossRef]

2. Ganopolski, A.; Calov, R. The role of orbital forcing, carbon dioxide and regolith in $100 \mathrm{kyr}$ glacial cycles. Clim. Past 2011, 7, 1415-1425. [CrossRef]

3. Milankovitch, M. Kanon der Erdbestrahlung und seine Anwendung auf das Eiszeitenproblem; Royal Serbian Academy Special Publication 132; Königlich Serbische Akademie: Belgrade, Serbia, 1941.

4. Gregoire, L.J.; Valdes, P.J.; Payne, A.J. The relative contribution of orbital forcing and greenhouse gases to the North American deglaciation. Geophys. Res. Lett. 2015, 42, 9970-9979. [CrossRef]

5. He, F.; Shakun, J.D.; Clark, P.U.; Carlson, A.E.; Liu, Z.Y.; Otto-Bliesner, B.L.; Kutzbach, J.E. Northern Hemisphere forcing of Southern Hemisphere climate during the last deglaciation. Nature 2013, 494, 81-85. [CrossRef]

6. Clark, P.U.; Dyke, A.S.; Shakun, J.D.; Carlson, A.E.; Clark, J.; Wohlfarth, B.; Mitrovica, J.X.; Hostetler, S.W.; McCabe, A.M. The Last Glacial Maximum. Science 2009, 325, 710-714. [CrossRef]

7. Crowley, T.J. North Atlantic Deep Water cools the southern hemisphere. Paleoceanography 1992, 7, 489-497. [CrossRef]

8. Barker, S.; Diz, P.; Vautravers, M.J.; Pike, J.; Knorr, G.; Hall, I.R.; Broecker, W.S. Interhemispheric Atlantic seesaw response during the last deglaciation. Nature 2009, 457, 1097-1102. [CrossRef] [PubMed]

9. Skinner, L.C.; Waelbroeck, C.; Scrivner, A.E.; Fallon, S.J. Radiocarbon evidence for alternating northern and southern sources of ventilation of the deep Atlantic carbon pool during the last deglaciation. Proc. Natl. Acad. Sci. USA 2014, 111, 5480-5484. [CrossRef]

10. Newnham, R.M.; Vandergoes, M.J.; Sikes, E.; Carter, L.; Wilmshurst, J.M.; Lowe, D.J.; McGlone, M.S.; Sandiford, A. Does the bipolar seesaw extend to the terrestrial southern mid-latitudes? Quat. Sci. Rev. 2012, 36, 214-222. [CrossRef]

11. Kawamura, K.; Parrenin, F.; Lisiecki, L.; Uemura, R.; Vimeux, F.; Severinghaus, J.P.; Hutterli, M.A.; Nakazawa, T.; Aoki, S.; Jouzel, J.; et al. Northern Hemisphere forcing of climatic cycles in Antarctica over the past 360,000 years. Nature 2007, 448, 912-916. [CrossRef]

12. Marshall, J.; Speer, K. Closure of the meridional overturning circulation through Southern Ocean upwelling. Nat. Geosci. 2012, 5, 171-180. [CrossRef]

13. Anderson, R.F.; Ali, S.; Bradtmiller, L.I.; Nielsen, S.H.H.; Fleisher, M.Q.; Anderson, B.E.; Burckle, L.H. Wind-Driven Upwelling in the Southern Ocean and the Deglacial Rise in Atmospheric $\mathrm{CO}_{2}$. Science 2009, 323, 1443-1448. [CrossRef]

14. Bauska, T.K.; Baggenstos, D.; Brook, E.J.; Mix, A.C.; Marcott, S.A.; Petrenko, V.V.; Schaefer, H.; Severinghaus, J.P.; Lee, J.E. Carbon isotopes characterize rapid changes in atmospheric carbon dioxide during the last deglaciation. Proc. Natl. Acad. Sci. USA 2016, 113, 3465-3470. [CrossRef] [PubMed] 
15. Menviel, L.; Spence, P.; Yu, J.; Chamberlain, M.A.; Matear, R.J.; Meissner, K.J.; England, M.H. Southern Hemisphere westerlies as a driver of the early deglacial atmospheric $\mathrm{CO}_{2}$ rise. Nat Commun 2018, 9, 2503. [CrossRef] [PubMed]

16. Dai, Y.; Yu, J.; Rafter, P.A. Deglacial ventilation changes in the deep Southwest Pacific. Paleoceanogr. Paleoclimatology 2021, 36, e2020PA004172. [CrossRef]

17. Monnin, E.; Indermuhle, A.; Dallenbach, A.; Fluckiger, J.; Stauffer, B.; Stocker, T.F.; Raynaud, D.; Barnola, J.M. Atmospheric CO 2 concentrations over the last glacial termination. Science 2001, 291, 112-114. [CrossRef] [PubMed]

18. Marcott, S.A.; Bauska, T.K.; Buizert, C.; Steig, E.J.; Rosen, J.L.; Cuffey, K.M.; Fudge, T.J.; Severinghaus, J.P.; Ahn, J.; Kalk, M.L.; et al. Centennial-scale changes in the global carbon cycle during the last deglaciation. Nature 2014, 514, 616-619. [CrossRef]

19. Sigman, D.M.; Hain, M.P.; Haug, G.H. The polar ocean and glacial cycles in atmospheric CO(2) concentration. Nature 2010, 466, 47-55. [CrossRef]

20. Adkins, J.F. The role of deep ocean circulation in setting glacial climates. Paleoceanography 2013, 28, 539-561. [CrossRef]

21. Lauderdale, J.M.; Williams, R.G.; Munday, D.R.; Marshall, D.P. The impact of Southern Ocean residual upwelling on atmospheric $\mathrm{CO}_{2}$ on centennial and millennial timescales. Clim. Dyn. 2017, 48, 1611-1631. [CrossRef]

22. Stein, K.; Timmermann, A.; Kwon, E.Y.; Friedrich, T. Timing and magnitude of Southern Ocean sea ice/carbon cycle feedbacks. Proc. Natl. Acad. Sci. USA 2020, 117, 4498-4504. [CrossRef] [PubMed]

23. Toggweiler, J.R.; Russell, J.L.; Carson, S.R. Midlatitude westerlies, atmospheric $\mathrm{CO}_{2}$, and climate change during the ice ages. Paleoceanography 2006, 21, PA2005. [CrossRef]

24. Morrison, A.K.; Hogg, A.M.; Ward, M.L. Sensitivity of the Southern Ocean overturning circulation to surface buoyancy forcing. Geophys. Res. Lett. 2011, 38, L14602. [CrossRef]

25. Munday, D.R.; Johnson, H.L.; Marshall, D.P. Eddy Saturation of Equilibrated Circumpolar Currents. J. Phys. Oceanogr. 2013, 43, 507-532. [CrossRef]

26. Morrison, A.K.; McC. Hogg, A. On the Relationship between Southern Ocean Overturning and ACC Transport. J. Phys. Oceanogr. 2013, 43, 140-148. [CrossRef]

27. Imbrie, J.; Boyle, E.A.; Clemens, S.C.; Duffy, A.; Howard, W.R.; Kukla, G.; Kutzbach, J.; Martinson, D.G.; McIntyre, A.; Mix, A.C.; et al. On the Structure and Origin of Major Glaciation Cycles 1. Linear Responses to Milankovitch Forcing. Paleoceanography 1992, 7, 701-738. [CrossRef]

28. Skinner, L.C. Glacial-interglacial atmospheric $\mathrm{CO}_{2}$ change: A possible "standing volume" effect on deep-ocean carbon sequestration. Clim. Past 2009, 5, 537-550. [CrossRef]

29. Skinner, L.C.; Fallon, S.; Waelbroeck, C.; Michel, E.; Barker, S. Ventilation of the deep Southern Ocean and deglacial $\mathrm{CO}_{2}$ rise. Science 2010, 328, 1147-1151. [CrossRef]

30. Kohfeld, K.E.; Graham, R.M.; de Boer, A.M.; Sime, L.C.; Wolff, E.W.; Le Quéré, C.; Bopp, L. Southern Hemisphere westerly wind changes during the Last Glacial Maximum: Paleo-data synthesis. Quat. Sci. Rev. 2013, 68, 76-95. [CrossRef]

31. Heusser, C.J. Southern Westerlies during the Last Glacial Maximum. Quat. Res. 1989, 31, 423-425. [CrossRef]

32. Lamy, F.; Hebbeln, D.; Wefer, G. High-Resolution Marine Record of Climatic Change in Mid-latitude Chile during the Last 28,000 Years Based on Terrigenous Sediment Parameters. Quat. Res. 1999, 51, 83-93. [CrossRef]

33. Heusser, L.; Heusser, C.; Mix, A.; McManus, J. Chilean and Southeast Pacific paleoclimate variations during the last glacial cycle: Directly correlated pollen and 8180 records from ODP Site 1234. Quat. Sci Rev. 2006, 25, 3404-3415. [CrossRef]

34. Heusser, L.; Heusser, C.; Pisias, N. Vegetation and climate dynamics of southern Chile during the past 50,000 years: Results of ODP Site 1233 pollen analysis. Quat. Sci Rev. 2006, 25, 474-485. [CrossRef]

35. McGlone, M.S.; Turney, C.S.M.; Wilmshurst, J.M.; Renwick, J.; Pahnke, K. Divergent trends in land and ocean temperature in the Southern Ocean over the past 18,000 years. Nat. Geosci. 2010, 3, 622-626. [CrossRef]

36. Markgraf, V. Late and postglacial vegetational and paleoclimatic changes in subantarctic, temperate, and arid environments in Argentina. Palynology 1983, 7, 43-70. [CrossRef]

37. Markgraf, V.; Bradbury, J.P.; Busby, J.R. Paleoclimates in Southwestern Tasmania during the Last 13,000 Years. Palaios 1986, 1, 368-380. [CrossRef]

38. Markgraf, V. Palaeoclimates in central and south America since 18,000 BP based on pollen and lake-level records. Quat. Sci Rev. 1989, 8, 1-24. [CrossRef]

39. Petit, J.R.; Jouzel, J.; Raynaud, D.; Barkov, N.I.; Barnola, J.M.; Basile, I.; Bender, M.; Chappellaz, J.; Davis, M.; Delaygue, G.; et al. Climate and atmospheric history of the past 420,000 years from the Vostok ice core, Antarctica. Nature 1999, 399, 429-436. [CrossRef]

40. Delmonte, B.; Petit, J.R.; Maggi, V. Glacial to Holocene implications of the new 27000-year dust record from the EPICA Dome C (East Antarctica) ice core. Clim. Dyn. 2002, 18, 647-660.

41. Wolff, E.W.; Fischer, H.; Fundel, F.; Ruth, U.; Twarloh, B.; Littot, G.C.; Mulvaney, R.; Rothlisberger, R.; de Angelis, M.; Boutron, C.F.; et al. Southern Ocean sea-ice extent, productivity and iron flux over the past eight glacial cycles. Nature 2002, 440, 491-496. [CrossRef]

42. Williams, N.J.; Harle, K.J.; Gale, S.J.; Heijnis, H. The vegetation history of the last glacial-interglacial cycle in eastern New South Wales, Australia. J. Quat. Sci. 2006, 21, 735-750. [CrossRef]

43. Rojas, M.; Moreno, P.; Kageyama, M.; Crucifix, M.; Hewitt, C.; Abe-Ouchi, A.; Ohgaito, R.; Brady, E.C.; Hope, P. The Southern Westerlies during the last glacial maximum in PMIP2 simulations. Clim. Dyn. 2009, 32, 525-548. [CrossRef] 
44. Chavaillaz, Y.; Codron, F.; Kageyama, M. Southern westerlies in LGM and future (RCP4.5) climates. Clim. Past 2013, 9, 517-524. [CrossRef]

45. Rojas, M. Sensitivity of Southern Hemisphere circulation to LGM and $4 \times \mathrm{CO}_{2}$ climates. Geophys. Res. Lett. 2013, 40, 965-970. [CrossRef]

46. Sime, L.C.; Kohfeld, K.E.; Le Quéré, C.; Wolff, E.W.; de Boer, A.M.; Graham, R.M.; Bopp, L. Southern Hemisphere westerly wind changes during the Last Glacial Maximum: Model-data comparison. Quat. Sci. Rev. 2013, 64, 104-120. [CrossRef]

47. Liu, W.; Lu, J.; Leung, L.R.; Xie, S.-P.; Liu, Z.; Zhu, J. The de-correlation of westerly winds and westerly-wind stress over the Southern Ocean during the Last Glacial Maximum. Clim. Dyn. 2015, 45, 3157-3168. [CrossRef]

48. Sime, L.C.; Hodgson, D.; Bracegirdle, T.J.; Allen, C.; Perren, B.; Roberts, S.; de Boer, A.M. Sea ice led to poleward-shifted winds at the Last Glacial Maximum: The influence of state dependency on CMIP5 and PMIP3 models. Clim. Past 2016, 12, $2241-2253$. [CrossRef]

49. Jiang, N.; Yan, Q. Evolution of the meridional shift of the subtropical and subpolar westerly jet over the Southern Hemisphere during the past 21,000 years. Quat. Sci. Rev. 2020, 246, 106544. [CrossRef]

50. Wyrwoll, K.-H.; Dong, B.; Valdes, P. On the position of southern hemisphere westerlies at the Last Glacial Maximum: An outline of AGCM simulation results and evaluation of their implications. Quat. Sci. Rev. 2000, 19, 881-898. [CrossRef]

51. Valdes, P.J. South American palaeoclimate model simulations: How reliable are the models? J. Quat. Sci. 2000, 15, 357-368 [CrossRef]

52. Kitoh, A.; Murakami, S.; Koide, H. A simulation of the Last Glacial Maximum with a coupled atmosphere-ocean GCM. Geophys. Res. Lett. 2001, 28, 2221-2224. [CrossRef]

53. Otto-Bliesner, B.L.; Brady, E.C.; Clauzet, G.; Tomas, R.; Levis, S.; Kothavala, Z. Last Glacial Maximum and Holocene Climate in CCSM3. J. Clim. 2006, 19, 2526-2544. [CrossRef]

54. Shin, S.I.; Liu, Z.; Otto-Bliesner, B.; Brady, E.; Kutzbach, J.; Harrison, S. A Simulation of the Last Glacial Maximum climate using the NCAR-CCSM. Clim. Dyn. 2003, 20, 127-151. [CrossRef]

55. Kim, S.J.; Flato, G.; Boer, G. A coupled climate model simulation of the Last Glacial Maximum, Part 2: Approach to equilibrium. Clim. Dyn. 2003, 20, 635-661. [CrossRef]

56. Brady, E.C.; Kay, J.E.; Otto-Bliesner, B.L.; Rosenbloom, N. Sensitivity to Glacial Forcing in the CCSM4. J. Clim. 2013, 26, 1901-1925. [CrossRef]

57. Abernathey, R.P.; Cerovecki, I.; Holland, P.R.; Newsom, E.; Mazloff, M.; Talley, L.D. Water-mass transformation by sea ice in the upper branch of the Southern Ocean overturning. Nat. Geosci. 2016, 9, 596-601. [CrossRef]

58. Liu, W.; Liu, Z.; Li, S. The Driving Mechanisms on Southern Ocean Upwelling Change during the Last Deglaciation. Geosciences 2021, 11, 266. [CrossRef]

59. Rintoul, S.; Hughes, C.; Olbers, D. Ocean Circulation and Climate. In The Antarctic Circumpolar Current System; Siedler, G., Church, J., Gould, J., Eds.; Academic Press: Cambridge, MA, USA, 2001; Volume 77.

60. Lund, D.C.; Chase, Z.; Kohfeld, K.E.; Wilson, E.A. Tracking Southern Ocean Sea Ice Extent With Winter Water: A New Method Based on the Oxygen Isotopic Signature of Foraminifera. Paleoceanogr. Paleoclimatology 2021, 36, e2020PA004095. [CrossRef]

61. Ferrari, R.; Jansen, M.F.; Adkins, J.F.; Burke, A.; Stewart, A.L.; Thompson, A.F. Antarctic sea ice control on ocean circulation in present and glacial climates. Proc. Natl. Acad. Sci. USA 2014, 111, 8753-8758. [CrossRef]

62. Watson, A.J.; Vallis, G.K.; Nikurashin, M. Southern Ocean buoyancy forcing of ocean ventilation and glacial atmospheric $\mathrm{CO}_{2}$. Nat. Geosci. 2015, 8, 861-864. [CrossRef]

63. Jansen, M.F.; Nadeau, L.-P. The Effect of Southern Ocean Surface Buoyancy Loss on the Deep-Ocean Circulation and Stratification. J. Phys. Oceanogr. 2016, 46, 3455-3470. [CrossRef]

64. Jansen, M.F. Glacial ocean circulation and stratification explained by reduced atmospheric temperature. Proc. Natl. Acad. Sci. USA 2017, 114, 45-50. [CrossRef] [PubMed]

65. Marzocchi, A.; Jansen, M.F. Global cooling linked to increased glacial carbon storage via changes in Antarctic sea ice. Nat. Geosci. 2019, 12, 1001-1005. [CrossRef]

66. Nadeau, L.-P.; Ferrari, R.; Jansen, M.F. Antarctic Sea Ice Control on the Depth of North Atlantic Deep Water. J. Clim. 2019, 32, 2537-2551. [CrossRef]

67. Bourassa, M.A.; Gille, S.T.; Bitz, C.; Carlson, D.; Cerovecki, I.; Clayson, C.A.; Cronin, M.F.; Drennan, W.M.; Fairall, C.W.; Hoffman, R.N.; et al. High-Latitude Ocean and Sea Ice Surface Fluxes: Challenges for Climate Research. B Am. Meteorol. Soc. 2013, 94, 403-423. [CrossRef]

68. Stephens, B.B.; Keeling, R.F. The influence of Antarctic sea ice on glacial-interglacial $\mathrm{CO}_{2}$ variations. Nature 2000, 404, 171-174. [CrossRef]

69. Fischer, H.; Schmitt, J.; Lüthi, D.; Stocker, T.F.; Tschumi, T.; Parekh, P.; Joos, F.; Köhler, P.; Völker, C.; Gersonde, R.; et al. The role of Southern Ocean processes in orbital and millennial $\mathrm{CO}_{2}$ variations-A synthesis. Quat. Sci. Rev. 2010, 29, 193-205. [CrossRef]

70. Karstensen, J.; Lorbacher, K. A practical indicator for surface ocean heat and freshwater buoyancy fluxes and its application to the NCEP reanalysis data. Tellus A Dyn. Meteorol. Oceanogr. 2011, 63, 338-347. [CrossRef]

71. Iudicone, D.; Madec, G.; Blanke, B.; Speich, S. The Role of Southern Ocean Surface Forcings and Mixing in the Global Conveyor. J. Phys. Oceanogr. 2008, 38, 1377-1400. [CrossRef] 
72. Saenko, O.A.; Schmittner, A.; Weaver, A.J. On the Role of Wind-Driven Sea Ice Motion on Ocean Ventilation. J. Phys. Oceanogr. 2002, 32, 3376-3395. [CrossRef]

73. Jacobs, S.S. Bottom water production and its links with the thermohaline circulation. Antarct. Sci. 2004, 16, 427-437. [CrossRef]

74. Talley, L. Closure of the Global Overturning Circulation Through the Indian, Pacific, and Southern Oceans: Schematics and Transports. Oceanography 2013, 26, 80-97. [CrossRef]

75. Timmermann, A.; Timm, O.; Stott, L.; Menviel, L. The Roles of $\mathrm{CO}_{2}$ and Orbital Forcing in Driving Southern Hemispheric Temperature Variations during the Last 21000 yr. J. Clim. 2009, 22, 1626-1640. [CrossRef]

76. Rutberg, R.L.; Broccoli, A.J. Response of the High-Latitude Southern Hemisphere to Precessional Forcing: Implications for Pleistocene Ocean Circulation. Paleoceanogr. Paleoclimatology 2019, 34, 1092-1106. [CrossRef]

77. Kaiser, E.A.; Billups, K.; Bradtmiller, L. A one million year record of biogenic silica in the Indian Ocean Sector of the Southern Ocean: Regional versus global forcing of primary productivity. Paleoceanogr. Paleoclimatology 2021, 36, e2020PA004033.

78. Liu, Z.; Otto-Bliesner, B.L.; He, F.; Brady, E.C.; Tomas, R.; Clark, P.U.; Carlson, A.E.; Lynch-Stieglitz, J.; Curry, W.; Brook, E.; et al. Transient simulation of last deglaciation with a new mechanism for Bolling-Allerod warming. Science 2009, 325, 310-314. [CrossRef]

79. Gent, P.R.; McWilliams, J.C. Isopycnal Mixing in Ocean Circulation Models. J. Phys. Oceanogr. 1990, 20, 150-155. [CrossRef]

80. Peltier, W.R. Global glacial isostasy and the surface of the ice-age earth: The ICE-5G (VM2) Model and GRACE. Annu. Rev. Earth Planet. Sci. 2004, 32, 111-149. [CrossRef]

81. Clark, P.U.; McCabe, A.M.; Mix, A.C.; Weaver, A.J. Rapid rise of sea level 19,000 years ago and its global implications. Science 2004, 304, 1141-1144. [CrossRef]

82. Fairbanks, R.G. A 17,000-year glacio-eustatic sea level record: Influence of glacial melting rates on the Younger Dryas event and deep-ocean circulation. Nature 1989, 342, 637-642. [CrossRef]

83. Stouffer, R.J.; Yin, J.; Gregory, J.M.; Dixon, K.W.; Spelman, M.J.; Hurlin, W.; Weaver, A.J.; Eby, M.; Flato, G.M.; Hasumi, H.; et al. Investigating the Causes of the Response of the Thermohaline Circulation to Past and Future Climate Changes. J. Clim. 2006, 19, 1365-1387. [CrossRef]

84. Clark, P.U.; Mitrovica, J.X.; Milne, G.A.; Tamisiea, M.E. Sea-level fingerprinting as a direct test for the source of global meltwater pulse IA. Science 2002, 295, 2438-2441. [CrossRef] [PubMed]

85. Bassett, S.E.; Milne, G.A.; Mitrovica, J.X.; Clark, P.U. Ice sheet and solid Earth influences on far-field sea-level histories. Science 2005, 309, 925-928. [CrossRef]

86. McManus, J.F.; Francois, R.; Gherardi, J.M.; Keigwin, L.D.; Brown-Leger, S. Collapse and rapid resumption of Atlantic meridional circulation linked to deglacial climate changes. Nature 2004, 428, 834-837. [CrossRef] [PubMed]

87. Otto-Bliesner, B.L.; Russell, J.M.; Clark, P.U.; Liu, Z.; Overpeck, J.T.; Konecky, B.; de Menocal, P.; Nicholson, S.E.; He, F.; Lu, $\mathrm{Z}$. Coherent changes of southeastern equatorial and northern African rainfall during the last deglaciation. Science 2014, 346, 1223-1227. [CrossRef]

88. Shi, J.; Yan, Q. Evolution of the Asian-African Monsoonal Precipitation over the last 21 kyr and the Associated Dynamic Mechanisms. J. Clim. 2019, 32, 6551-6569. [CrossRef]

89. Liu, Z.Y.; Lu, Z.Y.; Wen, X.Y.; Otto-Bliesner, B.L.; Timmermann, A.; Cobb, K.M. Evolution and forcing mechanisms of El Nino over the past 21,000 years. Nature 2014, 515, 550-553. [CrossRef]

90. Buizert, C.; Keisling, B.A.; Box, J.E.; He, F.; Carlson, A.E.; Sinclair, G.; DeConto, R.M. Greenland-Wide Seasonal Temperatures During the Last Deglaciation. Geophys. Res. Lett. 2018, 45, 1905-1914. [CrossRef]

91. Mandal, G.; Lee, S.-Y.; Yu, J.-Y. The Roles of Wind and Sea Ice in Driving the Deglacial Change in the Southern Ocean Upwelling: A Modeling Study. Sustainability 2021, 13, 353. [CrossRef]

92. Ronge, T.A.; Frische, M.; Fietzke, J.; Stephens, A.L.; Bostock, H.; Tiedemann, R. Southern Ocean contribution to both steps in deglacial atmospheric $\mathrm{CO}_{2}$ rise. Sci. Rep. 2021, 11, 22117. [CrossRef]

93. Chase, Z.; Anderson, R.F.; Fleisher, M.Q.; Kubik, P.W. Accumulation of biogenic and lithogenic material in the Pacific sector of the Southern Ocean during the past 40,000 years. Deep Sea Res. Part II Top. Stud. Oceanogr. 2003, 50, 799-832. [CrossRef]

94. Lauderdale, J.M.; Garabato, A.C.N.; Oliver, K.I.C.; Follows, M.J.; Williams, R.G. Wind-driven changes in Southern Ocean residual circulation, ocean carbon reservoirs and atmospheric $\mathrm{CO}_{2}$. Clim. Dyn. 2013, 41, 2145-2164. [CrossRef]

95. Sun, S.; Eisenman, I.; Stewart, A.L. The influence of Southern Ocean surface buoyancy forcing on glacial-interglacial changes in the global deep ocean stratification. Geophys. Res. Lett 2016, 43, 8124-8132. [CrossRef]

96. Fischer, H.; Fundel, F.; Ruth, U.; Twarloh, B.; Wegner, A.; Udisti, R.; Becagli, S.; Castellano, E.; Morganti, A.; Severi, M.; et al. Reconstruction of millennial changes in dust emission, transport and regional sea ice coverage using the deep EPICA ice cores from the Atlantic and Indian Ocean sector of Antarctica. Earth Planet. Sci. Lett. 2007, 260, 340-354. [CrossRef]

97. Chen, C.; Wang, G. Simulated Southern Ocean Upwelling at the Last Glacial Maximum and Early Deglaciation: The Role of Eddy-Induced Overturning Circulation. Geophys. Res. Lett. 2021, 48, e2021GL092880. [CrossRef]

98. Timmermann, A.; Friedrich, T.; Timm, O.E.; Chikamoto, M.O.; Abe-Ouchi, A.; Ganopolski, A. Modeling Obliquity and CO 2 Effects on Southern Hemisphere Climate during the Past 408 ka*. J. Clim. 2014, 27, 1863-1875. [CrossRef]

99. Haumann, F.A.; Gruber, N.; Munnich, M.; Frenger, I.; Kern, S. Sea-ice transport driving Southern Ocean salinity and its recent trends. Nature 2016, 537, 89-92. [CrossRef] [PubMed] 
100. Maksym, T. Climate science: Southern Ocean freshened by sea ice. Nature 2016, 537, 40-41. [CrossRef]

101. Bronselaer, B.; Winton, M.; Griffies, S.M.; Hurlin, W.J.; Rodgers, K.B.; Sergienko, O.V.; Stouffer, R.J.; Russell, J.L. Change in future climate due to Antarctic meltwater. Nature 2018, 564, 53-58. [CrossRef] 